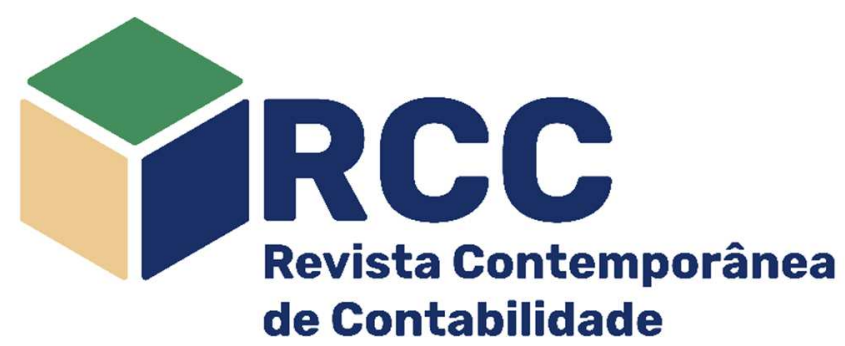

\title{
Análise do processo decisório dos investidores e analistas do mercado financeiro em relação às ações de empresas com patrimônio líquido negativo
}

Analysis of the decisional process of investors and financial market analysts in relation to the shares of companies with negative equity

\section{Análisis del proceso decisorio de los inversores y analistas del mercado financiero en relación con las acciones de empresas con patrimonio neto negativo}

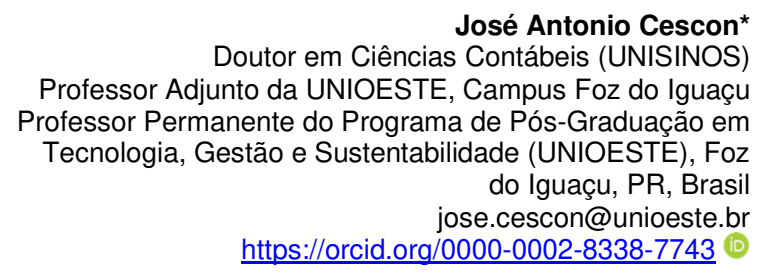

https://orcid.org/0000-0002-8338-7743 (1)

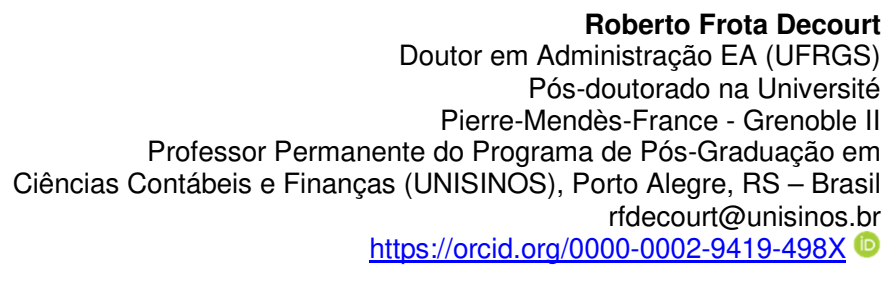

Luciana de Andrade Costa

Ph.D em Economia (Drexel University)

Coordenadora e Professora do Programa de Pós-Graduação

em Economia (UNISINOS)

landradec@unisinos.br

https://orcid.org/0000-0002-7575-2405

Endereço do contato principal para correspondência* Av. Tarquínio Joslin dos Santos - Jardim Universitário das Américas, CEP: 85870-650 - Foz do Iguaçu, PR, Brasil

\section{Resumo}

Este estudo buscou identificar as motivações dos investidores e analistas do mercado financeiro de aplicarem/recomendarem investimentos em empresas com Patrimônio Líquido Negativo (PLN). Para tanto, realizaram-se entrevistas com investidores (22) e analistas do mercado financeiro (09) que possuíram/possuem, recomendaram/recomendam a compra, venda, manutenção de ações de empresas com PLN. O método utilizado foi a Análise de Conteúdo, suportada pela premissa da Hipótese do Mercado Eficiente (HME) e das Finanças Comportamentais (FC). A análise conduziu a três categorias no processo de formação da tomada de decisão: a primeira - "Processo racional" - atende à HME, de que tanto o investidor quanto os analistas são racionais; a segunda- "Processo pseudorracional"- atende parcialmente à HME, como as FC; e a terceira - "Processo comportamental"- atende às FC. Os resultados demonstram que, individualmente nem os investidores ou analistas entrevistados podem ser classificados dentro de uma categoria específica, não havendo, neste sentido, um processo totalmente racional, pseudorracional ou comportamental.

Palavras-chave: Tomada de Decisão; Finanças Comportamentais; Vieses Comportamentais; Investidores; Analistas do Mercado Financeiro

\footnotetext{
Abstract

This study sought to identify the motivations of investors and financial market analysts to apply/recommend investments in companies with negative equity (NE). For this purpose, interviews were conducted with investors (22) and financial market analysts (09) who have or have recommended/recommend the purchase, sale, maintenance of shares of companies with Negative Equity. The method used was Content Analysis, supported by the premise of the Efficient Market Hypothesis (EMH) and Behavioral Finance (BF). The analysis led to three categories in the process of forming decision-making: the first - "Rational process" - serves EMH,
} 
that both investors and analysts are rational; the second - "Pseudorational process" - partially meets EMH, such as BF; and the third - "Behavioral process" - serves the BF. The results demonstrate that, individually neither the investors or analysts interviewed can be classified within a specific category, and there is, in this sense, a totally rational, pseudorational or behavioral process.

Keywords: Decision Making; Behavioral Finance; Behavioral Bias; Investors; Financial Market Analysts

\section{Resumen}

Este estudio buscó identificar las motivaciones de los inversores y analistas del mercado financiero de aplicar/recomendar inversiones en empresas con Patrimonio Neto Negativo (PNN). Para ello, se realizaron entrevistas con inversores (22) y analistas del mercado financiero (09) que poseyeron/poseen, recomendaron/recomiendan la compra, venta, mantenimiento de acciones de empresas con PNN. El método utilizado fue el Análisis de Contenido, soportado por la premisa de la Hipótesis del Mercado Eficiente (HME) y de las Finanzas Comportamentales (FC). El análisis condujo a tres categorías en el proceso de formación de la toma de decisiones: la primera - "Proceso racional" - sirve a HME, que tanto los inversores como los analistas son racionales; el segundo, "Proceso pseudoracional" - cumple parcialmente con HME, como FC; y el tercero - "Proceso conductual" - sirve a la FC. Los resultados demuestran que, individualmente, ni los inversores, ni los analistas entrevistados pueden clasificarse dentro de una categoría específica, no habiendo, en este sentido, un proceso totalmente racional, pseudoracional o conductual.

Palabras clave: Toma de decisión; Finanzas de comportamiento; Vieses de comportamiento; Inversores; Analistas del mercado financiero

\section{Introdução}

A Moderna Teoria de Finanças tem, em seu pressuposto, que os investidores agem de forma racional, que são avessos ao risco e que os mercados são eficientes (FAMA, 1970). Se tal premissa estiver correta, como explicar por que investidores e analistas do mercado financeiro decidem adquirir e/ou manter ações de empresas com PLN, já que, em tese, essas empresas estão prontas para a liquidação? (BROWN et al., 2008; JAN e OU, 2012 e ANG, 2015).

No contexto do mercado de capitais, o ambiente de informações para a tomada de decisão é dinâmico e complexo. Sob a ótica da Moderna Teoria de Finanças, o processo decisório é racional, de maneira que os indivíduos o realizam de forma eficiente (MARKOWITZ, 1952; ROBERTS, 1959; OSBORNE, 1959; SHARPE, 1966; FAMA, 1970). Porém, Simon (1957), questionou essa racionalidade ilimitada, afirmando que, nem sempre, os indivíduos respeitam os fundamentos da Teoria da Utilidade Esperada, segundo a qual o valor das coisas deve ser baseado na utilidade que elas proporcionam, e não nos seus preços. Com a eficiência de mercado sendo questionada, como lidar, então, com situações não explicáveis pelos modelos baseados na racionalidade ilimitada dos agentes na Hipótese do Mercado Eficiente (HME), cerne do paradigma das finanças modernas?

Barberis e Thaler (2003) consideram que uma das causas dessa dificuldade passe pelo surgimento de uma nova abordagem - as Finanças Comportamentais - cuja premissa é que a teoria financeira convencional ignora de que forma as pessoas tomam decisões, visto que, ao contrário, é possível pensar de forma coerente nos preços de ativos, incorporando aspectos salientes do comportamento humano (BARBERIS; THALER, 2003).

No sentido apontado pelos autores, além das informações que desempenham papel fundamental no processo de formação da tomada de decisão, há de se considerar o aspecto comportamental do investidor e do analista do mercado financeiro na formação desse processo decisório. Dito de outra forma, no processo decisório há vieses, julgamentos que se amparam nos pressupostos das Finanças Comportamentais (TVERSKY; KAHNEMAN, 1979).

Estudos recentes, no Brasil (CAZZARI, 2017; SILVA, 2016; BRAGA, 2015; GOULART, 2014) e no âmbito Internacional (AINIA; LUTFI, 2019; ENGSTED; PEDERSEN, 2016; COELHO et al. 2014; NAWROCKI; VIOLE, 2014, HAN; KUMAR, 2013), aliados ao prêmio Nobel de economia concedido a Richard Thaler em 2017, por suas pesquisas sobre a Contabilidade Mental no final do século passado, têm suscitado a discussão sobre o processo da tomada de decisão por agentes do mercado de capitais sob a ótica das Finanças Comportamentais e suas implicações para o mercado financeiro, Neste sentido, como no estudo de Braga (2015), uma contribuição deste estudo, é demonstrar uma integração entre a teoria moderna de finanças e a teoria de finanças comportamentais.

Investidores e analistas do mercado financeiro podem não estar seguindo um plano de investimento baseado em percepções estritamente racionais, mas tendo a formação de seu processo da tomada de decisão afetada por vieses comportamentais. Nesse cenário, há de se considerar as empresas com PLN, pois os investimentos em ações de empresas com PLN podem estar sendo determinados por questões comportamentais, fundadas em questões que envolvem emoção, e não razão.

Nesse contexto, destaca-se que os investimentos no mercado de capitais, segundo Bodie et al. (2015), envolvem riscos ao investidor e que, no caso das empresas com PLN, esses riscos podem ser classificados como especulação ou aposta. Além disso, tem-se verificado que existe um elevado número de 
empresas que apresentam PLN com valor de mercado positivo, fato que tem instigado pesquisadores a buscarem os elementos que determinariam essa situação. Uma análise nas demonstrações contábeis das empresas ativas listadas na B3, indicam que entre os anos 2000 a 2018, em média 11\% destas empresas apresentaram PLN, portanto tendo suas ações negociadas regularmente por investidores e possuíam cobertura de analistas. Tal como nas pesquisas internacionais, por exemplo, de Fama e French $(1992,2015)$; Hayn (1995); Collins, Pincus e Xie (1999); Jenkins (2003); Brown et al. (2008); Hsu e Etheridge (2009); Jan e Ou (2012); Hou, Zhang e Zhuang (2015); e Ang (2015), e respaldado pelo crescente interesse acadêmico e profissional acerca destas empresas com PLN, justifica-se o estudo, além de na atualidade, constituir-se em lacuna nas pesquisas de finanças no Brasil.

O exposto levou ao seguinte questionamento: O processo decisório de investidores e analistas do mercado financeiro de investir em empresas com PLN é puramente racional ou é afetado também por aspectos comportamentais? Desse questionamento derivou o estudo ora apresentado o qual teve, como objetivo, identificar as motivações dos investidores e analistas do mercado financeiro de aplicarem/recomendarem investimentos em empresas com PLN.

A proposta deste estudo sustenta que os investidores e os analistas do mercado, no processo de construção de estratégias de investimentos em relação às ações de empresas com PLN, fundamentam suas decisões em questões racionais e objetivam maximizar o resultado do investimento, em conformidade com a Moderna Teoria de Finanças. Todavia, não é ignorado que algumas dessas decisões podem violar os princípios da racionalidade e, conforme a teoria das Finanças Comportamentais, esses desvios da racionalidade não são aleatórios, sendo muitos deles, vieses que podem ser explicados com base em questões emocionais.

Apresenta-se o estudo neste artigo o qual contém, além da Introdução e das Considerações Finais, - Referencial Teórico, os Procedimentos Metodológicos e a Apresentação e Análise dos Resultados, respectivamente segundo; terceiro e quarto tópicos.

\section{Referencial Teórico}

A Moderna Teoria de Finanças, já mencionada, é composta por um corpo de conhecimento de várias teorias, tendo como base a teoria econômica neoclássica. Pressupõe que: i) os investidores agem de forma racional no mercado, são avessos ao risco e buscam a maximização da utilidade esperada por meio do uso de expectativas racionais e informação perfeita; ii) os mercados são altamente eficientes; e iii) os investidores exploram todas as oportunidades de arbitragem.

Em resumo, essa teoria pressupõe agentes capazes de decidir estritamente de acordo com uma racionalidade ilimitada, está metodologicamente estruturada com a Teoria da Utilidade Esperada e não apresenta vieses acerca do futuro (THALER, 1999).

As finanças modernas se desenvolveram a partir de 1950 e, de acordo com Haugen (2005), os principais trabalhos surgidos a partir dessa época ainda são adotados como modelos no mundo das finanças. Entre eles, se destacam os trabalhos de: Markowitz (1952), cujos conceitos ainda hoje são utilizados para a precificação e a diversificação dos ativos de investimentos; Simon (1957), que questiona a racionalidade ilimitada dos indivíduos; Modigliani e Miller (1958, 1961), que demonstram que o valor de uma empresa não é dependente de sua política de dividendos; Sharpe (1964), responsável pelo surgimento, na década de 1960, do Capital Asset Pricing Model (CAPM), que predomina até hoje para determinar o custo de capital das empresas; Fama (1970), autor da Teoria dos Mercados Eficientes, considerada um dos pilares das finanças modernas; Ross (1975), com a Teoria de Precificação por Arbitragem (APT); Tversky e Kahneman (1979), com a Teoria do Prospecto, base das Finanças Comportamentais.

Os trabalhos citados foram marcantes para os estudos sobre finanças e, mesmo recebendo críticas, conseguiram explanar sobre os fenômenos que se propuseram explicar. Destaca-se que abordar a Moderna Teoria de Finanças implica em discutir a Hipótese dos Mercados Eficientes (HME) que, segundo Fama (1970) se desenvolveu tendo como pilar os estudos realizados por Markowitz (1952), Modigliani e Miller (1958, 1961) e Sharpe (1964).

\subsection{A Hipótese do Mercado Eficiente}

A HME, desenvolvida por Fama $(1970,1991)$, teve como base os conceitos desenvolvidos por Roberts (1959) e Osborne (1959). Esses estudiosos trouxeram, em seus artigos, descobertas empíricas acerca da aleatoriedade dos preços das ações, ou seja, descobriram que as informações relevantes das empresas negociadas no mercado são incorporadas aos preços dos ativos e que a melhor estimativa para 0 preço de um título é seu preço atual.

Quanto às suas pressuposições, a HME pode ser caracterizada da seguinte maneira: i) não exige que o preço de mercado seja igual ao valor real a cada instante; requer que os preços de mercado não sejam tendenciosos ou que se possam encontrar preços acima ou abaixo daquele e que esses desvios sejam aleatórios; ii) os desvios aleatórios devem ter a mesma probabilidade de serem acima ou abaixo do valor real, sendo importante que não sejam correlacionáveis com qualquer variável observável; iii) dessa forma, nenhum 
grupo de investidores, utilizando qualquer estratégia de investimentos, será capaz de conseguir encontrar ações mal apreçadas constantemente (DAMODARAM, 2006).

Para testar as formas de eficiência de mercados, Fama (1970) dividiu os testes com base em três conjuntos de informação: i) informações passadas (preço histórico), forma fraca; ii) informações publicamente disponíveis, forma semiforte; e iii) todo o conjunto de informação (informações passadas, públicas e privadas), forma forte. Estas formas foram renomeadas por Fama (1991). Assim, o teste de previsibilidade de retornos substituiu a denominação da forma fraca; o teste da forma semiforte passou a ser denominado estudo de eventos e, por fim, o teste de informações privadas substituiu a forma forte.

No que se refere às informações passadas (preço histórico), forma fraca, a HME indica que o mercado incorpora completamente as informações sobre os preços passados dos títulos, ou seja, nenhum investidor consegue obter retornos anormais por meio da análise dos preços passados, além de que as informações contidas nos preços passados não são úteis ou relevantes na obtenção de retornos anormais (FAMA, 1970).

Quanto às informações publicamente disponíveis, forma semiforte, a HME defende que os preços não refletem apenas o histórico do comportamento de preços, mas também todas as informações publicamente disponíveis, incluindo as demonstrações financeiras das empresas, notícias, comunicados e as demais informações. Nessa forma, nenhum investidor consegue obter retornos anormais baseado nas informações públicas pelo fato de que os preços se ajustam rapidamente sempre que novas informações são divulgadas.

Em se tratando de todo o conjunto de informação (informações passadas, públicas e privadas), forma forte, a HME considera que toda informação relevante, pública ou privada, está refletida no preço dos ativos. Assim, por exemplo, um insider de posse de informações privadas não conseguiria auferir retornos anormais, pois o ajuste dos preços no mercado é instantâneo. Para a forma forte da HME, os testes de eficiência são feitos com investidores que possuem acesso a informações privadas. Os testes, nessa forma de eficiência, buscam detectar se investidores se beneficiam com resultados anormais a partir de informações privilegiadas que não estariam refletidas nos preços (FAMA, 1991).

Em contrariedade à Moderna Teoria de Finanças, o processo de escolha na tomada de decisão nem sempre é simples (SOUZA et al., 2006). A admissão da racionalidade limitada, na qual somente fatores que estão estreitamente ligados, causal e temporalmente, podem ser levados em consideração para a tomada de decisão, não é real. Esse cenário é somente uma simplificação do processo decisório (SIMON, 1957).

De acordo com Yoshinaga et al. (2008), a introdução de abordagens alternativas para a compreensão das "anomalias", vistas com certa regularidade nos mercados, são contestações aos teóricos que postulam a racionalidade dos agentes econômicos na explicação satisfatória dos fenômenos financeiros.

Uma das ideias fundamentais para as Finanças Comportamentais é a Teoria do Prospecto, desenvolvida por Tversky e Kahneman (1974; 1979), baseada na noção de racionalidade limitada de Simon (1957). Os trabalhos desenvolvidos por Tversky e Kahneman, entre 1974 e 1979, fundamentam as teorias que possibilitam examinar o comportamento de investidores, avaliando as influências de aspectos psicológicos no que se refere à compreensão do processo decisório do homem frente aos riscos (FERREIRA et al., 2009). Tversky e Kahneman (1979), com a Teoria do Prospecto, buscaram explicar os vieses cognitivos (ou heurísticos) nos processos decisórios, pois a tomada de decisão não é apenas racional, devido, sobretudo, à existência de limitação do tempo disponível para a ação de decidir.

Dessa forma, os indivíduos, ao decidirem utilizar atalhos mentais, estão sujeitos a vieses em função das seguintes ilusões: i) Efeito Certeza, originado pela propensão dos investidores de enfatizar as possibilidades com maior probabilidade de ocorrência; ii) Efeito Reflexão/Aversão à Perda, que ocorre quando os agentes tendem a ser contrários ao risco frente a duas possibilidades de ganhos com a mesma utilidade esperada, bem como a aceitar os riscos quando as mesmas possibilidades se apresentam no domínio das perdas; e iii) Efeito Isolamento, que ocorre quando os indivíduos, visando simplificar a decisão, desconsideram parte das características de cada opção de escolha e centralizam sua análise nos componentes que distinguem as opções de escolha (ROGERS et al., 2007).

\subsection{A Teoria do Prospecto}

A Teoria do Prospecto oferece diversos vieses de decisão, estando entre eles: Enquadramento; Contabilidade Mental; Aversão à Perda e Fuga ao Arrependimento; Efeito Disjunção; Efeito Manada; Excesso de Confiança; llusão Monetária; e Gambling Investors.

Sob a perspectiva do Enquadramento, uma mesma opção pode ser enquadrada ou descrita de diferentes maneiras (TVERSKY; KAHNEMAN, 1981), da mesma forma que os resultados possíveis de uma aposta podem ser enquadrados como ganhos e perdas em relação ao status quo ou como condições de ativo que incorporam a riqueza inicial. A invariância exige que tais mudanças na descrição dos resultados não devam alterar a ordem de preferência (KAHNEMAN, 2012).

Por sua vez, a Contabilidade Mental, processo no qual os indivíduos organizam seus investimentos de forma separada, resulta em respostas conflitantes a uma mesma situação decisória e, consequentemente, em ineficiência do processo decisório. Os agentes usam orçamentos financeiros para monitorar e controlar seus gastos, enquanto o cérebro usa orçamentos mentais para associar os benefícios do consumo aos 
custos, em cada uma de suas contas mentais (MACEDO; FONTES, 2010).

Já Aversão à Perda e Fuga ao Arrependimento são fenômenos tão ligados, não se conseguindo, muitas vezes, distinguir a ocorrência de um ou de outro. A Aversão à Perda é considerada um dos pilares das Finanças Comportamentais (SHEFRIN; STATMAN, 1985). Para Tverski e Kahneman (1979), os investidores sentem muito mais a dor da perda do que o prazer obtido com um ganho equivalente, pois o investidor pondera tanto os ganhos quanto as perdas, mas não dá a ambos o mesmo valor psicológico.

Para Tversky e Kahneman (1979), ao olharmos para nossas escolhas por opções ruins, percebemos que somos propensos à busca de risco no campo das perdas e propensos à aversão à perda no campo dos ganhos. Tverski e Kahneman (1979), definem a aversão ao risco, como a preferência comum que as pessoas em geral exibem por uma coisa segura em vez de uma aposta favorável de valor esperado igual ou ligeiramente maior. As decisões de investimento de investidores podem ser influenciadas pelo nível de tolerância ao risco, que é uma atitude demonstrada pelos investidores ao avaliar um risco, principalmente se estes riscos estão relacionados a incertezas sobre os retornos do investimento (AINIA; LUTFI, 2019). Investidores dispostos a aceitar ou tolerar riscos tendem a ser corajosos na alocação de recursos para ativos de alto risco e vice-versa (CORTER; CHEN, 2006).

Quanto ao Efeito Disjunção, segundo Tversky e Shafir (1992), corresponde à tendência de os indivíduos adiarem suas decisões até que a informação seja revelada, mesmo que essa informação não seja tão relevante para a sua decisão ou que não tenha ligação com a decisão.

No que tange ao Efeito Manada, pesquisas que visam identificá-lo nos investidores do mercado de capitais têm se baseado nos estudos de Scharfstein e Stein (1990) e Lakonishok, Shleifer e Vishny (1992). Mas, o que pode levar ao comportamento de rebanho aos investidores? Para Scharfstein e Stein (1990), sob certas circunstâncias, os investidores simplesmente imitam as decisões de investimento de outros, ignorando a informação confidencial substantiva. Embora esse comportamento seja ineficiente do ponto de vista social, pode ser racional a partir da perspectiva dos gestores que estão preocupados com a sua reputação perante o mercado (SCHARFSTEIN; STEIN, 1990).

O Excesso de Confiança, por sua vez, de acordo com Kahneman (2012), é um comportamento característico presente em boa parte da população mundial. Isso explica por que cerca de $80 \%$ das pessoas, ao se referirem as suas habilidades, tais como capacidade de liderança, motorista e relacionamento com outras pessoas, entre outras, consideram-se acima da média.

Para Lichtenstein e Fischhoff (1977), as pessoas tendem a achar que estão em situação melhor do que realmente estão e julgam com frequência que estão mais corretas do que na verdade estão. Em sua maioria, os investidores consideram as suas habilidades de vencer o mercado como acima da média, o que pode surpreender investidores desprevenidos, levando-os a situações em que podem ser perdidas grandes quantidades de dinheiro.

No que diz respeito à llusão Monetária, foi definida por Leontief (1936) como uma violação do postulado de homogeneidade. Tal postulado estipula que as funções de demanda e oferta são homogêneas de grau zero em todos os preços nominais, o que significa que eles dependem apenas de preços relativos, e não de preços absolutos (FEHR; TYRAN, 2001).

Segundo Fehr e Tyran (2001), a intuição, por trás da definição de Leontief (1936), diz que, se a situação objetiva individual permanece inalterada, as decisões reais de um indivíduo livre de ilusão também não mudam. São duas as suposições cruciais subjacentes a essa intuição: primeiro, a função objetiva do indivíduo não depende de valores nominais, mas apenas de magnitudes reais; em segundo lugar, as pessoas percebem que as mudanças puramente nominais não afetam sua oportunidade definida. Por exemplo, as pessoas entendem que uma mudança equiparada em todas as magnitudes nominais não afeta as restrições reais.

No tocante a Gambling Investors, estudos têm apresentado evidências de uma preferência dos investidores por ativos com retornos, tais como "loteria ou grandes ganhos", isto é, ativos que apresentem probabilidade relativamente pequena de uma grande recompensa. Em função disso, muitos investidores estão diversificando pouco sua carteira de investimentos, optando por apostar tudo em um ativo como se fosse um bilhete de loteria (BALI; CAKICI; WHITELAW, 2011). Han e Kumar (2013) relatam, adicionalmente, que ações com características especulativas (ou seja, preço baixo, alta assimetria idiossincrática e de volatilidade) são o habitat preferido de investidores de varejo com uma forte propensão para jogar.

Por fim, além do processo racional e comportamental na formação de tomada de decisão do investidor e analista, este estudo insere o processo pseudorracional, aqui utilizado de forma análoga aos estudos de Kurdoglu (2019), que em seu estudo, com base na teoria da legitimação, investigou como os gerentes das organizações lidam com alegações de injustiça. Os resultados do estudo demonstraram que os gerentes para se defenderem dessas acusações, se utilizam de escolhas de valores sem a precisão da lógica formal. Estes valores são não racionais, mas não irracionais.

\section{Procedimentos Metodológicos}

A pesquisa realizada teve uma abordagem qualitativa e pode ser classificada como pesquisa de campo. A população foi composta por investidores e analistas do mercado financeiro que atuam no mercado 
de capitais do Brasil e que possuem/possuíram ou, ainda, indicam/indicaram ações de empresas que estão ou estiveram em, pelo menos, um trimestre com PLN, considerados os últimos cinco anos (de 2013 a 2017). Essa composição, quanto aos investidores, se deu por meio de consulta à base de dados da Economática das empresas com PLN nas demonstrações financeiras no final do exercício de 2016. Também se acessou o link dessas empresas por meio do site da Brasil, Bolsa e Balcão (B3), onde realizou-se uma busca pelo nome, e-mail e contato do responsável pela Relação com Investidores (RI). Da mesma forma, se teve acesso, no que se refere aos investidores, ao link de cobertura de analistas por meio do site da B3 em busca do nome e do contato dos analistas cadastrados e se fez visitas a algumas corretoras de valores cadastradas na Comissão de Valores Mobiliários (CVM) e a um analista independente.

O processo de seleção da amostragem foi não probabilístico, pois partiu de um universo restrito, e a escolha dos seus componentes se deu por conveniência do pesquisador. Tal procedimento traz algumas limitações de inferência, o que não invalida o resultado da pesquisa, já que o objetivo era identificar as motivações dos investidores e analistas do mercado financeiro de aplicarem/recomendarem investimentos em empresas com PLN. A amostra ficou composta por 22 acionistas e 09 analistas do mercado financeiro, aos quais se aplicaram entrevistas semiestruturadas, de forma presencial, por Skype ${ }^{\mathrm{TM}}$ ou por telefone, através de um conjunto de perguntas pré-definidas, porém com espaço para novos questionamentos.

Na construção das questões pré-definidas, apresentadas aos investidores e aos analistas do mercado financeiro, adotaram-se os seguintes procedimentos: Identificar, na literatura existente sobre Finanças Comportamentais, os principais fatores que influenciam o processo decisório do investidor e do analista do mercado; Submeter e validar as questões a um analista, a um investidor e a um pesquisador, para que fosse indicado um elemento de consenso para o roteiro de questionamentos na entrevista.

A entrevista do tipo formal ou semiestruturada segue um plano determinado de ação e é empregada quando se deseja informações em profundidade que possam ser obtidas em locais privados e com respondentes recrutados em locais predeterminados (CHENITZ; SWANSON, 1986). A base para a quantificação do número de entrevistas deste estudo foi a saturação teórica, conforme proposto por Glaser e Strauss (1967), a qual ocorreu, para os investidores, na $14^{\mathrm{a}}$ entrevista e, para os analistas, na $5^{\mathrm{a}}$, e percebeuse que novas entrevistas não adicionavam novas informações de interesse para esse estudo. O tempo médio das entrevistas foi de 00:18:46 de um total de 06:53:01 para os investidores e de 00:16:08 de um total de 02:25:16 para os analistas, e respectivamente com 4,64 e 4,56 as médias de páginas editadas de transcrição.

No Quadro 1, apresentam-se as perguntas utilizadas neste estudo, de quais vieses elas se originaram, bem como suas referências-base na literatura.

Quadro 1: Perguntas da pesquisa

\begin{tabular}{|c|c|c|}
\hline Viés Racional & Pergunta & Referência \\
\hline $\begin{array}{l}\text { No ambiente de informações para } \\
\text { análise de desempenho da } \\
\text { empresa num Processo Racional, } \\
\text { quais informações são utilizadas. }\end{array}$ & $\begin{array}{l}\text { Em relação à Empresa, ao Negócio e ao Mercado, quais são os principais } \\
\text { indicadores (ordem de importância) na formação do processo decisório? } \\
\text { (Índices de Liquidez; Endividamento Geral; Alavancagem Operacional; } \\
\text { Imobilizações do PL; Rentabilidade do PL; Giro do Ativo; Crescimento das } \\
\text { Vendas; Margem Líquida; Tamanho da Empresa; Participação no } \\
\text { Mercado; Concorrência; Setor do Mercado; Política Governamental). }\end{array}$ & $\begin{array}{l}\text { Fama (1970); } \\
\text { Damodaram } \\
\text { (2006); }\end{array}$ \\
\hline Viés Comportamental & Pergunta & Referência \\
\hline Contabilidade Mental & $\begin{array}{l}\text { - Você determina um montante para investimentos, tais como previdência } \\
\text { privada, CDB, CDI, LTN, Poupança, Ações, etc.? } \\
\text { - Considere a seguinte situação; na data de vencimento de seu cartão de } \\
\text { crédito, você tem disponível 50\% dos recursos para liquidar a fatura. Você } \\
\text { deixa o restante para a fatura seguinte ou resgata de uma de suas } \\
\text { aplicações. Qual e por que o resgate dessa aplicação? }\end{array}$ & $\begin{array}{c}\text { Tversky e } \\
\text { Kahneman (1979) } \\
\text { Thaler (1999) }\end{array}$ \\
\hline $\begin{array}{l}\text { Aversão à Perda } \\
\text { Enquadramento }\end{array}$ & $\begin{array}{l}\text { Quando você monta um determinado portfólio de investimentos, você } \\
\text { forma uma expectativa de ganho ou de perda. Em termos percentuais, } \\
\text { quais seriam essas expectativas para o prazo de um ano? } \\
\text { O que você faria se um determinado ativo desse portfólio, esta semana, } \\
\text { subisse } 50 \% \text { do que você estimou para o ano? E se caísse } 50 \% \text { ? }\end{array}$ & $\begin{array}{c}\text { Kahneman } \\
(2012) ; \\
\text { Tversky e } \\
\text { Kahneman (1979) }\end{array}$ \\
\hline Fuga ao Arrependimento & $\begin{array}{l}\text { - Em quais investimentos você se arrependeu de ter entrado e em quais } \\
\text { investimentos você se arrependeu de não ter entrado? } \\
\text { - Como o fato de você ter se arrependido de ter entrado no investimento } \\
\text { afetou a sua decisão na oportunidade seguinte? } \\
\text { - Como o fato você ter perdido a oportunidade influenciou a sua decisão } \\
\text { na oportunidade seguinte? } \\
\text { - Você se sente mais seguro quando segue e/ou consulta um analista de } \\
\text { mercado? }\end{array}$ & Kahneman (2012) \\
\hline Efeito Disjunção & $\begin{array}{l}\text { - Você fez investimentos em uma empresa que está em dificuldades } \\
\text { financeiras e entrou com pedido de recuperação judicial. Na próxima } \\
\text { semana, sairá o resultado desse pedido. } \\
\text { Considerando as seguintes possibilidades, qual seria sua atitude: }\end{array}$ & $\begin{array}{c}\text { Tversky e Shafir } \\
\text { (1992) }\end{array}$ \\
\hline
\end{tabular}




\begin{tabular}{|c|c|c|}
\hline Viés Comportamental & Pergunta & Referência \\
\hline Efeito Disjunção & $\begin{array}{l}\text { * A recuperação judicial será aceita com um bom acordo entre as partes, } \\
\text { e o mercado estima o bom lucro nessas ações. Nesse caso, você } \\
\text { aguardará o resultado para vender as ações com um bom lucro.* A } \\
\text { recuperação judicial não será aceita, e o mercado estima uma perda } \\
\text { considerável nessa ação. Nesse caso, você vende essas ações antes do } \\
\text { resultado, mesmo com prejuízo. } \\
\text { * Não há indicativo de como será o resultado desse pedido. Como está } \\
\text { muito indefinido, você sairá dessa posição antes do resultado? }\end{array}$ & $\begin{array}{l}\text { Tversky e Shafir } \\
\text { (1992) }\end{array}$ \\
\hline $\begin{array}{c}\text { Loteria } \\
\text { (Gambling Investors) }\end{array}$ & $\begin{array}{l}\text { - Se você for fazer um investimento em ações que possuem baixo valor, } \\
\text { qual é sua estratégia: você procura se informar mais sobre esse ativo ou } \\
\text { simplesmente faz o investimento, já que, se perder, o montante da perda } \\
\text { será pouco? }\end{array}$ & $\begin{array}{c}\text { Han e Kumar } \\
\text { (2013); } \\
\text { Bali et al. (2011) }\end{array}$ \\
\hline $\begin{array}{l}\text { Efeito Manada } \\
\text { Aversão à Perda } \\
\text { Fuga ao Arrependimento } \\
\text { Enquadramento }\end{array}$ & $\begin{array}{l}\text { - Você possui investimentos em ações que estão lhe proporcionando } \\
\text { ganhos e em ações que estão em queda? } \\
\text { - O movimento do mercado está com alta volatilidade em ambas as } \\
\text { situações. } \\
\text { - Você acompanharia o movimento do mercado em ambas ou apenas na } \\
\text { que está lhe proporcionando ganho ou naquela que está em queda? }\end{array}$ & $\begin{array}{c}\text { Cipriani e } \\
\text { Guarino (2008); } \\
\text { Kahneman (2012) }\end{array}$ \\
\hline \multirow{3}{*}{$\begin{array}{l}\text { Excesso de Confiança } \\
\text { Otimismo }\end{array}$} & $\begin{array}{l}\text { - Ao fazer um investimento, você tem a convicção de que suas } \\
\text { informações são melhores e mais confiáveis que as dos outros } \\
\text { investidores que atuam no mesmo mercado. }\end{array}$ & Odean (1998) \\
\hline & $\begin{array}{l}\text { - Embora você disponha de informações que possam ser coletadas na } \\
\text { mídia e/ou no meio de atuação, você acredita mais nas informações que } \\
\text { você já possui, ou buscaria novas informações para decidir? }\end{array}$ & Kahneman (2012) \\
\hline & $\begin{array}{l}\text { - Ao pensar sobre seus investimentos, você passa mais tempo pensando } \\
\text { sobre o retorno potencial ou sobre a possível perda? }\end{array}$ & $\begin{array}{l}\text { Benartzi, } \\
\text { Kahneman e } \\
\text { Thaler (1999), }\end{array}$ \\
\hline $\begin{array}{l}\text { Ilusão Monetária } \\
\text { Enquadramento }\end{array}$ & $\begin{array}{l}\text { - Há dois anos, você havia definido que o valor de venda de determinada } \\
\text { empresa era } R \$ 50 \text { /ação. Aparentemente, esta semana, a ação chegará } \\
\text { a este valor e nenhum fato novo surgiu. Continua (mais, menos ou } \\
\text { igualmente inclinado) com suas ações a venda por } R \$ 50 \text { ? }\end{array}$ & $\begin{array}{l}\text { Shafir, Diamond e } \\
\text { Tversky (1997); } \\
\text { Cardoso et. al. } \\
\text { (2010) }\end{array}$ \\
\hline
\end{tabular}

Fonte: Elaborado e adaptado pelos autores.

As perguntas (Quadro 1) feitas aos entrevistados se originaram de uma categorização predefinida. As entrevistas foram gravadas, transcritas e preparadas para posterior análise. $O$ passo seguinte foi a tabulação, a análise e a interpretação do material coletado. Para tanto, se optou pela Análise de Conteúdo e se tomaram, como base, os três momentos no tratamento dos dados estabelecidos por Bardin (2009): i) a pré-análise - realizada durante o processo de transcrição das entrevistas, momento em que se avaliou a amplitude das respostas e dos registros que se fez sobre as impressões da coleta de dados; ii) a exploração do material - que compreendeu a codificação e a categorização das entrevistas em categorias iniciais e categorias finais; e iii) o tratamento dos resultados, inferência e interpretação - que possibilitou a identificação da resposta ao problema de pesquisa.

A constituição das categorias, ocorreu após leitura prévia e releituras das entrevistas transcritas, o que possibilitou a comparação entre o processo de formação de tomada de decisão e as categorias que são comuns aos investidores e analistas do mercado financeiro.

As categorias iniciais foram inferências oriundas de interpretações acerca das respostas aos questionamentos e situações apresentados aos entrevistados, enquanto a constituição das categorias finais decorreu de interações e elevação do nível de análise das categorias iniciais. Em síntese, a partir das categorias iniciais produziram-se inferências acerca do processo de tomada de decisão do investidor e do analista do mercado financeiro, tendo sido, portanto, a construção das categorias finais respaldada pelas categorias iniciais. Foram três as categorias finais da análise de conteúdo realizada:

1. "Processo racional na formação da tomada de decisão";

2. "Processo pseudorracional na formação da tomada de decisão";

3. "Processo comportamental na formação da tomada de decisão".

Na Figura 1, apresenta-se exemplo do processo de construção das categorias iniciais e das categorias finais no desenvolvimento da análise de conteúdo. Seguindo esse processo, expõe-se, na Figura 2, a estrutura geral de derivação das categorias previamente definidas em categorias iniciais e em categorias finais para o desenvolvimento da Análise de Conteúdo. 
Figura 1: Exemplo do processo de construção das categorias de análise

\begin{tabular}{|l|l|l|l|}
\hline \multicolumn{2}{|c|}{ Categoria préviamente definida: Ambiente de informações para análise de desempenho da empresa. } \\
\hline \multicolumn{2}{|c|}{ Questão 1: Em relação à Empresa, ao Negócio e ao Mercado, quais são os principais indicadores na } \\
formação do processo decisório.
\end{tabular}

Fonte: Elaborada e adaptada pelos autores.

Figura 2: Processo de derivação das categorias de análise

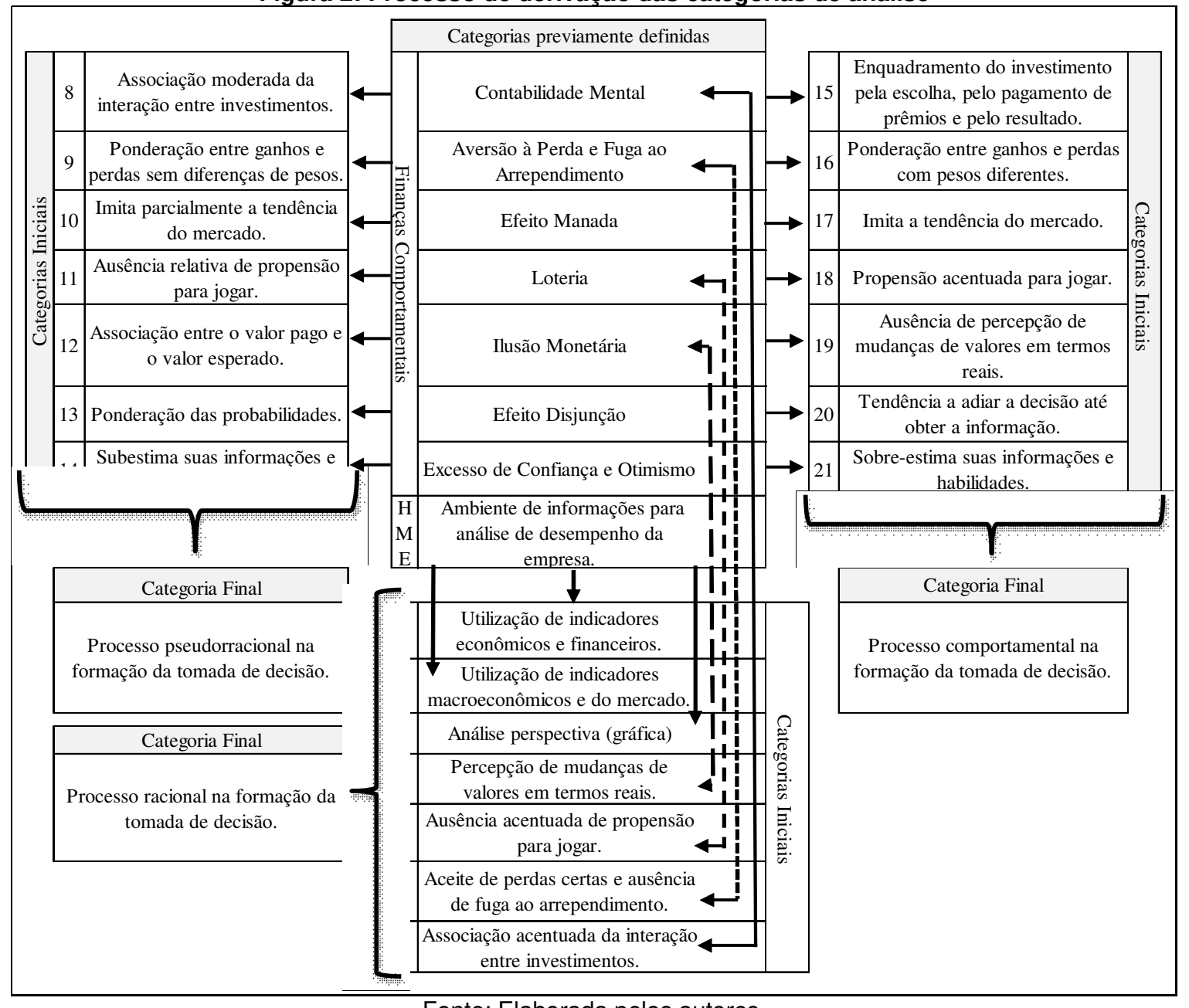

Fonte: Elaborada pelos autores.

As categorias expostas na Figura 2 derivaram, como já mencionado, de um processo baseado na inferência entre os significados, as afirmações, as alusões ou negações contidas nas respostas que deram origem às categorias iniciais, ora agrupadas em categorias finais, cujo caráter é mais abrangente.

Há de se destacar que, na categoria final "Processo pseudorracional na formação da tomada de decisão", se considera que, tanto o investidor quanto o analista, ao realizarem assertivas sobre o processo de formação da tomada de decisão, consideram como racionais tais assertivas, porém elas são compostas de aspectos comportamentais em sua construção. Este estudo não abordou a precificação dos ativos das empresas com PLN. A abordagem foi sobre como se dá o processo de formação da tomada de decisão de investidores e analistas do mercado financeiro.

\section{Apresentação e Análise dos Resultados}

Apresenta-se a Análise de Conteúdo que se realizou das entrevistas por meio do posicionamento dos investidores e analistas do mercado financeiro participantes da pesquisa frente às 3 (três) categorias finais referentes ao processo de formação da tomada de decisão. 


\subsection{Categoria Final - Processo racional na formação da tomada de decisão}

A primeira categoria final resultou da junção de sete categorias iniciais, originárias das categorias previamente definidas, (apresentadas na Figura 2). No quadro 2, apresentam-se as categorias iniciais e 0 processo de derivação da $1^{1 \underline{a}}$ categoria final, bem como os conceitos norteadores de ligação das categorias iniciais a essa categoria final.

Quadro 2: Categoria final "Processo racional na formação da tomada de decisão": processo de derivação e os conceitos norteadores

\begin{tabular}{|c|c|c|c|}
\hline \multicolumn{2}{|r|}{ Categorias Iniciais } & Conceito Norteador & $\begin{array}{c}\text { Categoria } \\
\text { Final }\end{array}$ \\
\hline 1 & $\begin{array}{l}\text { Utilização de indicadores econômicos e } \\
\text { financeiros }\end{array}$ & $\begin{array}{l}\text { As decisões são tomadas tendo como base os indicadores das } \\
\text { informações relacionadas à empresa e ao negócio. }\end{array}$ & \multirow{7}{*}{$\begin{array}{l}\text { I. Processo } \\
\text { racional na } \\
\text { formação da } \\
\text { tomada de } \\
\text { decisão }\end{array}$} \\
\hline 2 & $\begin{array}{l}\text { Utilização de indicadores } \\
\text { macroeconômicos e do mercado }\end{array}$ & $\begin{array}{l}\text { As decisões são tomadas tendo como base os indicadores das } \\
\text { informações relacionadas ao ambiente macro e do mercado. }\end{array}$ & \\
\hline 3 & Análise perspectiva (gráfica) & $\begin{array}{l}\text { As decisões são tomadas tendo como base a análise técnica (gráfica) } \\
\text { do comportamento do ativo no mercado financeiro. }\end{array}$ & \\
\hline 4 & $\begin{array}{l}\text { Percepção de mudanças de valores em } \\
\text { termos reais }\end{array}$ & $\begin{array}{l}\text { A tomada de decisão é realizada com a associação entre o valor pago } \\
\text { e o valor esperado e a percepção de mudanças de valores em termos } \\
\text { reais. }\end{array}$ & \\
\hline 5 & $\begin{array}{l}\text { Ausência acentuada de propensão } \\
\text { para jogar }\end{array}$ & $\begin{array}{l}\text { A tomada de decisão é realizada com a ponderação das } \\
\text { probabilidades e a ausência de propensão para jogar. }\end{array}$ & \\
\hline 6 & $\begin{array}{l}\text { Aceite de perdas certas e ausência de } \\
\text { fuga ao arrependimento }\end{array}$ & $\begin{array}{l}\text { A tomada de decisão é realizada com o aceite de perdas certas, } \\
\text { quando há uma ponderação entre ganhos e perdas sem diferença de } \\
\text { pesos, associada à ausência de sentimento de fuga ao } \\
\text { arrependimento. }\end{array}$ & \\
\hline 7 & $\begin{array}{l}\text { Associação acentuada da interação } \\
\text { entre investimentos }\end{array}$ & $\begin{array}{l}\text { A tomada de decisão é realizada quando há uma associação } \\
\text { contundente de interação entre investimentos. }\end{array}$ & \\
\hline
\end{tabular}

Fonte: Elaborado pelos autores.

O processo de transição das três primeiras categorias iniciais para a categoria final "Processo racional na formação da tomada de decisão", expostas no Quadro 2, pode ser descrito como uma "análise prospectiva" e constituiu-se numa síntese da visão preditiva do investidor e/ou analista do mercado financeiro que, a partir da análise de negócios, da análise contábil e da análise financeira, faz previsões sobre o futuro da empresa. Embora haja uma grande diferença entre as duas primeiras categorias iniciais, cuja base é a análise fundamentalista em relação à terceira categoria inicial, a qual tem por base a análise técnica, ambas estão suportadas pela racionalidade do investidor e/ou analista do mercado.

Em relação às três categorias iniciais, pode-se inferir que "o processo de formação da tomada de decisão é suportado pelo uso de informações disponíveis aos agentes do mercado financeiro". Na inferência realizada na categoria inicial "Utilização de indicadores econômicos e financeiros", constatou-se que os investidores, quando questionados sobre quais indicadores relacionados à empresa, ao negócio e ao mercado eram os mais importantes para a formação da tomada de decisão, citaram um ou dois indicadores, sendo que o principal fator apontado foi a utilização de índices de liquidez e a situação patrimonial.

Considerando que os investidores participantes desta pesquisa são ou foram possuidores de ações com PLN, como explicar, então, a opção por esse tipo de investimento, já que o que importa, em essência, para esses investidores é a capacidade de liquidez da empresa e o seu patrimônio líquido ser positivo, não havendo, portanto, sentido investir em empresas cujo patrimônio líquido tecnicamente não existe mais.

Nesse caso, o investidor e o analista buscam identificar, na empresa, indicadores preditivos de que essa empresa possui indicativo de reversão de PLN. Logo, segundo eles, esse ativo está subprecificado e possui potencial para proporcionar retorno positivo no futuro. Da mesma maneira, isso pode ser explicado e/ou aceito em relação à análise técnica, cujo estudo de comportamentos passados justifica a tendência de ganho futuro. Essa análise está em consonância com os estudos de ludícibus (2009).

No que concerne ao processo de transição das demais categorias iniciais para a categoria final "Processo racional na formação da tomada de decisão", pode-se inferir que essas categorias evidenciam que os investidores e analistas do mercado financeiro, frente a situações da tomada de decisão, optam pela decisão racional, agindo, portanto, com ausência de influência de vieses comportamentais.

Assim, pressupõe-se que as pessoas sejam racionais, que todas as informações sejam efetivamente processadas pelos agentes decisórios e que os mercados sejam eficientes, de maneira que cada decisão é tomada de modo a maximizar sua utilidade esperada. Nesse sentido, o processo de formação da tomada de decisão é suportado pela ausência de vieses comportamentais.

A associação contundente entre ganhos e perdas no enquadramento de investimentos, o aceite de perdas certas em que o investidor e/ou analista não demonstre que possa arrepender-se no futuro pela decisão tomada, negar-se a simplesmente apostar num determinado investimento e a percepção de que há mudanças de valores em termos reais, mesmo que não haja mudanças em termos nominais, caracterizam uma análise racional da situação para a tomada de decisão. 
O enquadramento do investimento pelo resultado, o aceite da perda com racionalidade, a ponderação entre ganhos e perdas sem diferença de pesos, a ausência de sentimento de fuga ao arrependimento, a ponderação das probabilidades, a ausência de propensão para jogar, a associação entre o valor pago e o valor esperado e a percepção de mudanças de valores em termos reais, nessa categoria final, embora presentes nos estudos de Tverski e Kahneman (1979); Shefrin e Statman (1985); e Engsted e Pederson (2016), são consideradas negações aos seus pressupostos.

A análise que se fez da categoria final "Processo racional na formação da tomada de decisão" permite assumir que o processo de formação da tomada de decisão do investidor e do analista do mercado financeiro é racional quando estes utilizam as informações disponíveis ou possíveis de serem extraídas por qualquer agente, uma vez que os indicadores de desempenho, tanto da empresa quanto do mercado financeiro, são públicos. Isso significa assumir que os preços das ações refletem adequadamente quaisquer informações disponíveis aos investidores e analistas, o que é base da HME (FAMA, 1970; FAMA; FRENCH, 1992).

\subsection{Categoria final - Processo pseudorracional na formação da tomada de decisão}

A exemplo da primeira categoria final, a segunda também resultou da junção de sete categorias iniciais, originárias das categorias previamente definidas (apresentadas na Figura 2). O Quadro 3 apresenta as categorias iniciais e o processo de derivação desta categoria final.

\begin{tabular}{|c|c|c|c|}
\hline \multicolumn{2}{|r|}{ Categoria Inicial } & Conceito Norteador & Categoria Final \\
\hline 8 & $\begin{array}{l}\text { Associação } \\
\text { moderada da } \\
\text { interação entre } \\
\text { investimentos }\end{array}$ & $\begin{array}{l}\text { Nesse processo de formação da tomada de decisão, embora haja uma parcela } \\
\text { de racionalidade no entendimento do investidor e/ou analista, esta é } \\
\text { influenciada pelo viés comportamental, não havendo, portanto, uma distinção } \\
\text { clara de predominância entre o viés racional e o viés comportamental. }\end{array}$ & \multirow{7}{*}{$\begin{array}{l}\text { II. Processo } \\
\text { pseudorracional na } \\
\text { formação da tomada } \\
\text { de decisão }\end{array}$} \\
\hline 9 & $\begin{array}{l}\text { Ponderação entre } \\
\text { ganhos e perdas sem } \\
\text { diferenças de pesos }\end{array}$ & $\begin{array}{l}\text { Nesse processo de formação da tomada de decisão, há uma aceitação de } \\
\text { perdas e ganhos sem que haja diferenças de pesos entre essas duas decisões } \\
\text { e ainda ambas possuem uma fuga moderada ao arrependimento. Dessa } \\
\text { forma, embora não haja um peso diferente entre ganhos e perdas, isso não } \\
\text { significa que não seja considerado pelo investidor e/ou analista. }\end{array}$ & \\
\hline 10 & $\begin{array}{l}\text { Imita parcialmente a } \\
\text { tendência do } \\
\text { mercado. }\end{array}$ & $\begin{array}{l}\text { Nesse processo de formação da tomada de decisão, os comportamentos nas } \\
\text { decisões de investidores e analistas não seguem estritamente o mercado. }\end{array}$ & \\
\hline 11 & $\begin{array}{l}\text { Ausência relativa de } \\
\text { propensão para jogar }\end{array}$ & $\begin{array}{c}\text { Nesse processo de formação da tomada de decisão, há uma ponderação das } \\
\text { probabilidades. }\end{array}$ & \\
\hline 12 & $\begin{array}{l}\text { Associação entre o } \\
\text { valor pago e o valor } \\
\text { esperado }\end{array}$ & $\begin{array}{l}\text { Nesse processo de formação da tomada de decisão, o investidor e o analista } \\
\text { não percebem claramente a mudança de valor em termos reais, mas não são } \\
\text { totalmente alheios a essa percepção. }\end{array}$ & \\
\hline 13 & $\begin{array}{l}\text { Ponderação das } \\
\text { probabilidades }\end{array}$ & $\begin{array}{l}\text { Nesse processo de formação da tomada de decisão, investidores e analistas } \\
\text { assumem uma posição em que há uma ponderação de probabilidades e } \\
\text { pensam nas suas transações (investimentos) em termos conjunturais. }\end{array}$ & \\
\hline 14 & $\begin{array}{l}\text { Subestima suas } \\
\text { informações e } \\
\text { habilidades }\end{array}$ & $\begin{array}{l}\text { Nesse processo de formação da tomada de decisão, investidores e analistas } \\
\text { possuem confiança moderada nas suas informações e habilidades, bem como } \\
\text { possuem um otimismo ou pessimismo moderado. }\end{array}$ & \\
\hline
\end{tabular}
Fonte: Elaborado pelos autores.

No que se refere ao processo de transição das categorias iniciais para a categoria final "Processo pseudorracional na formação da tomada de decisão", pôde-se inferir que tais categorias evidenciam que os investidores e analistas do mercado financeiro, frente a situações da tomada de decisão, embora considerem que optaram por uma decisão racional, portanto, entendem que agem com ausência de influência de vieses comportamentais. Isso, porém, não se confirmou com a análise de suas respostas frente aos questionamentos que visavam, exatamente, verificar o grau de racionalidade presente em cada resposta e/ou posicionamento.

Assim, constatou-se na entrevista, que os investidores e analistas, embora se considerem racionais, em parte do processo de formação da tomada de decisão, são suscetíveis a alguma influência de vieses comportamentais. Dessa maneira, não é possível afirmar que, a tomada de decisão, em seu processo de formação, seja racional, como também não é possível afirmar que esse processo seja predominantemente comportamental, razão pela qual recebeu a classificação pseudorracional.

Como apresentado na categoria final "Processo racional na formação da tomada de decisão", assumiram-se os pressupostos da HME de que as decisões dos investidores e analistas são racionais. Nessa segunda categoria final, embora, para os investidores e analistas, seus posicionamentos sejam racionais, esses posicionamentos estão imbuídos de certos aspectos comportamentais. Portanto, seu processo de formação da tomada de decisão é pseudorracional.

\subsection{Categoria final - Processo comportamental na formação da tomada de decisão}

A terceira categoria final igualmente resultou da junção de sete categorias iniciais, originárias das categorias previamente definidas, expostas na Figura 2. O Quadro 4 apresenta as categorias iniciais e a 
derivação da terceira categoria final, ou seja, "Processo comportamental na formação da tomada de decisão".

\begin{tabular}{|c|c|c|c|}
\hline \multicolumn{2}{|r|}{ Categoria Inicial } & Conceito Norteador & Categoria Final \\
\hline 15 & $\begin{array}{l}\text { Enquadramento do } \\
\text { investimento pela escolha, } \\
\text { pelo pagamento de prêmios e } \\
\text { pelo resultado }\end{array}$ & $\begin{array}{l}\text { Nesse processo de formação da tomada de decisão, o investidor e/ou } \\
\text { analista, ao determinarem montantes para os diversos tipos de } \\
\text { investimentos, não associam os benefícios de consumo desses } \\
\text { investimentos aos custos. Ainda há certa negligência na interação } \\
\text { entre investimentos. }\end{array}$ & \multirow{7}{*}{$\begin{array}{l}\text { III. Processo } \\
\text { comportamental na } \\
\text { formação da } \\
\text { tomada de decisão }\end{array}$} \\
\hline 16 & $\begin{array}{l}\text { Ponderação entre ganhos e } \\
\text { perdas com pesos diferentes }\end{array}$ & $\begin{array}{l}\text { Investidores e analistas atribuem pesos diferentes para ganhos e } \\
\text { perdas. Assim, quando retardam a venda das ações perdedoras e há } \\
\text { uma rápida realização dos ganhos, estes estão buscando fugir ao } \\
\text { arrependimento; portanto, a decisão é tomada sob a influência do viés } \\
\text { comportamental. }\end{array}$ & \\
\hline 17 & Imita a tendência do mercado. & $\begin{array}{l}\text { Investidores e analistas acompanham o movimento do mercado, } \\
\text { independentemente de ser um ativo ganhador ou perdedor. }\end{array}$ & \\
\hline 18 & $\begin{array}{l}\text { Propensão acentuada para } \\
\text { jogar }\end{array}$ & $\begin{array}{l}\text { Investidores optam por apostar em ativos como se fosse um bilhete de } \\
\text { loteria. }\end{array}$ & \\
\hline 19 & $\begin{array}{l}\text { Ausência de percepção de } \\
\text { mudanças de valores em } \\
\text { termos reais }\end{array}$ & $\begin{array}{c}\text { Investidores e analistas não percebem mudanças de valores em } \\
\text { termos reais em relação ao investimento. }\end{array}$ & \\
\hline 20 & $\begin{array}{l}\text { Tendência a adiar a decisão } \\
\text { até obter a informação }\end{array}$ & $\begin{array}{l}\text { Investidores e analistas esperam por informações para realizar a } \\
\text { tomada de decisão, mesmo que essa informação já seja esperada ou } \\
\text { seja irrelevante. }\end{array}$ & \\
\hline 21 & $\begin{array}{l}\text { Sobre-estima suas } \\
\text { informações e habilidades. }\end{array}$ & $\begin{array}{l}\text { Há um excesso de confiança dos investidores e analistas no que diz } \\
\text { respeito a informações e habilidades utilizadas para a tomada de } \\
\text { decisão, bem como há um otimismo exacerbado quanto ao resultado } \\
\text { esperado do investimento. }\end{array}$ & \\
\hline
\end{tabular}

Fonte: Elaborado pelos autores.

No processo de transição das categorias iniciais para a categoria final "Processo comportamental na formação da tomada de decisão", foi possível inferir que essas categorias evidenciam que os investidores e analistas do mercado financeiro, frente a situações da tomada de decisão, agem sob a influência de vieses comportamentais. Assim, é possível afirmar que esse processo de formação da tomada de decisão seja predominantemente comportamental.

O processo de convergência para a categoria final "Processo comportamental na formação da tomada de decisão" constitui confirmações dos estudos de Thaler (1999) sobre Contabilidade Mental; Kahneman e Tverski (1979), Aversão a Perdas; Shefrin e Statman (1985), Fuga ao Arrependimento; Tversky e Shafir (1992), Efeito Disjunção; Han e Kumar (2013) e Bali et al. (2011), Efeito Loteria; Cipriani e Guarino (2008) e Kahneman (2012), Efeito Manada; Odean (1998) e Benartzi et. al., (1999), Excesso de Confiança e Otimismo; e Shafir et. al., (1997) e Engsted e Pederson (2016), Efeito da llusão Monetária.

$\mathrm{Na}$ terceira categoria final, portanto, há uma contestação dos pressupostos da HME de que as decisões dos investidores e analistas sejam racionais. Nessa categoria final, o que se aponta é que investidores e analistas, em seus posicionamentos, estão imbuídos de aspectos comportamentais e que, portanto, seu processo de formação da tomada de decisão é comportamental.

Na sequência, apresenta-se, respectivamente, nas figuras 3 e 4, um mapa-resumo do posicionamento do investidor e do analista do mercado financeiro frente às 3 (três) categorias finais referentes ao processo de formação da tomada de decisão. Na Figura 5 se expõe, o teste de média de investidores versus analistas no que se refere aos seus posicionamentos.

Como esperado, observa-se, na Figura 4 (soma geral) que $84 \%$ dos entrevistados têm um processo racional de tomada de decisão, relativo ao Ambiente de informações para análise de desempenho da empresa, do negócio e do mercado. Nesse sentido, os investidores e os analistas utilizam as informações disponíveis para a tomada de decisão. Observa-se, também, a ausência desse processo racional em relação ao Excesso de Confiança e ao Otimismo, ou seja, para os entrevistados, não há um processo racional nesses vieses. Ainda há uma pequena incidência em relação ao Efeito Disjunção, com apenas $6 \%$ dos entrevistados sendo racionais.

Nesse processo racional, destacam-se ainda o Efeito Loteria, com $39 \%$ dos entrevistados sendo racionais em sua tomada de decisão, e $39 \%$ dos entrevistados que se mostraram racionais no processo de tomada de decisão frente ao viés Contabilidade Mental e 32\%, frente aos vieses Aversão à Perda e Fuga ao Arrependimento.

No processo pseudorracional, a maior incidência ocorreu quanto ao comportamento relacionado à Fuga ao Arrependimento, com $52 \%$ dos entrevistados formando suas decisões nesse viés, e com $39 \%$ dos entrevistados tomando suas decisões pseudorracionais em relação à Contabilidade Mental e ao Efeito Loteria. A menor incidência desse processo pseudorracional observou-se no processo de decisão relativo ao Ambiente de informações para análise de desempenho da empresa, do negócio e do mercado, com apenas $3 \%$ dos entrevistados. 
Figura 3: Mapa-resumo de decisão do investidor

\begin{tabular}{|c|c|c|c|c|c|c|c|c|c|c|c|c|c|c|c|c|c|c|c|c|c|c|c|c|c|c|c|c|c|c|c|c|c|c|}
\hline \multirow{2}{*}{\multicolumn{2}{|c|}{$\begin{array}{c}\text { Vieses bases } \\
\text { Entrevista }\end{array}$}} & \multicolumn{3}{|c|}{$\begin{array}{c}\text { Ambiente de } \\
\text { informações } \\
\text { para análise de } \\
\text { desempenho }\end{array}$} & \multicolumn{3}{|c|}{$\begin{array}{c}\text { Contabilidade } \\
\text { mental }\end{array}$} & \multicolumn{3}{|c|}{$\begin{array}{c}\text { Aversão à } \\
\text { perda }\end{array}$} & \multicolumn{3}{|c|}{$\begin{array}{c}\text { Fuga ao } \\
\text { arrependimento }\end{array}$} & \multicolumn{3}{|c|}{ Loteria } & \multicolumn{3}{|c|}{$\begin{array}{c}\text { Efeito } \\
\text { disjunção }\end{array}$} & \multicolumn{3}{|c|}{ Efeito manada } & \multicolumn{3}{|c|}{$\begin{array}{l}\text { Excesso de } \\
\text { confiança }\end{array}$} & \multicolumn{3}{|c|}{ Otimismo } & \multicolumn{3}{|c|}{$\begin{array}{l}\text { Ilusão } \\
\text { monetária }\end{array}$} & \multicolumn{3}{|c|}{$\begin{array}{l}\text { Observações categoria } \\
\text { final por entrevista }\end{array}$} \\
\hline & & $\mathbf{R}$ & $\mathbf{P}$ & $\mathrm{C}$ & $\mathbf{R}$ & $\mathbf{P}$ & $\mathbf{C}$ & $\mathbf{R}$ & $\mathbf{P}$ & C & $\mathbf{R}$ & $\mathbf{P}$ & $\mathbf{C}$ & $\mathbf{R}$ & $\mathbf{P}$ & $\mathrm{C}$ & $\mathbf{R}$ & $\mathbf{P}$ & $\mathbf{C}$ & $\mathbf{R}$ & $\mathbf{P}$ & $\mathrm{C}$ & $\mathbf{R}$ & $\mathbf{P}$ & $\mathbf{C}$ & $\mathbf{R}$ & $\mathbf{P}$ & $\mathrm{C}$ & $\mathbf{R}$ & $\mathbf{P}$ & $\mathbf{C}$ & $\mathbf{R}^{*}$ & $\mathbf{P} * *$ & $\mathbf{C} * * *$ \\
\hline \multirow{22}{*}{ 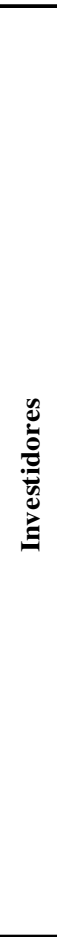 } & 1 & $\square$ & & & & 0 & & $\square$ & & & $\square$ & & & & & 0 & & & 0 & & & 0 & & 0 & & & 0 & & & & 0 & 3 & 3 & 4 \\
\hline & 2 & $\square$ & & & $\square$ & & & & & 0 & & 0 & & $\square$ & & & & & 0 & & & 0 & & & 0 & & & 0 & & 0 & & 3 & 2 & 5 \\
\hline & 3 & $\square$ & & & & & 0 & $\square$ & & & $\square$ & & & & 0 & & & & 0 & & & 0 & & & 0 & & 0 & & & 0 & & 3 & 3 & 4 \\
\hline & 4 & $\square$ & & & & 0 & & $\square$ & & & & 0 & & & 0 & & & 0 & & & & 0 & & 0 & & & & 0 & & 0 & & 2 & 6 & 2 \\
\hline & 5 & $\square$ & & & $\square$ & & & & 0 & & & 0 & & & & 0 & & & 0 & & 0 & & & & 0 & & & 0 & & 0 & & 2 & 4 & 4 \\
\hline & 6 & & 0 & & & 0 & & & 0 & & $\square$ & & & & & 0 & & & 0 & & & 0 & & 0 & & & 0 & & & & 0 & 1 & 5 & 4 \\
\hline & 7 & $\square$ & & & & 0 & & & & 0 & & & 0 & & 0 & & & & 0 & & & 0 & & & 0 & & & 0 & & & 0 & 1 & 2 & 7 \\
\hline & 8 & $\square$ & & & & & 0 & & 0 & & & 0 & & & 0 & & & & 0 & & 0 & & & 0 & & & 0 & & & & 0 & 1 & 6 & 3 \\
\hline & 9 & $\square$ & & & & & 0 & & & 0 & & 0 & & & 0 & & & & 0 & & 0 & & & & 0 & & & 0 & & & 0 & 1 & 3 & 6 \\
\hline & 10 & & & 0 & $\square$ & & & & & 0 & & 0 & & & & 0 & & & 0 & & 0 & & & & 0 & & & 0 & & & 0 & 1 & 2 & 7 \\
\hline & 11 & & & 0 & $\square$ & & & & & 0 & & 0 & & & & 0 & & & 0 & & & 0 & & & 0 & & & 0 & & & 0 & 1 & 1 & 8 \\
\hline & 12 & $\square$ & & & $\square$ & & & & & 0 & & & 0 & & 0 & & & 0 & & & 0 & & & 0 & & & 0 & & & & 0 & 2 & 5 & 3 \\
\hline & 13 & $\square$ & & & $\square$ & & & $\square$ & & & & & 0 & & 0 & & & & 0 & & & 0 & & & 0 & & 0 & & & & 0 & 3 & 2 & 5 \\
\hline & 14 & $\square$ & & & & 0 & & $\square$ & & & $\square$ & & & $\square$ & & & & & 0 & & & 0 & & & 0 & & & 0 & & & 0 & 4 & 1 & 5 \\
\hline & 15 & $\square$ & & & & 0 & & & & 0 & & & 0 & $\square$ & & & & & 0 & & & 0 & & & 0 & & & 0 & & 0 & & 2 & 2 & 6 \\
\hline & 16 & $\square$ & & & $\square$ & & & $\square$ & & & $\square$ & & & & & 0 & & & 0 & & & 0 & & & 0 & & 0 & & & & 0 & 4 & 1 & 5 \\
\hline & 17 & $\square$ & & & $\square$ & & & & & 0 & & 0 & & & 0 & & & 0 & & & & 0 & & & 0 & & & 0 & $\square$ & & & 3 & 3 & 4 \\
\hline & 18 & $\square$ & & & $\square$ & & & $\square$ & & & $\square$ & & & & & 0 & & & 0 & & & 0 & & 0 & & & & 0 & & 0 & & 4 & 2 & 4 \\
\hline & 19 & $\square$ & & & $\square$ & & & & 0 & & & 0 & & & 0 & & & & 0 & $\square$ & & & & 0 & & & 0 & & $\square$ & & & 4 & 5 & 1 \\
\hline & 20 & & & 0 & & 0 & & $\square$ & & & $\square$ & & & & 0 & & & & 0 & & & 0 & & & 0 & & & 0 & & & 0 & 2 & 2 & 6 \\
\hline & 21 & $\square$ & & & & & 0 & & & 0 & & 0 & & $\square$ & & & & & 0 & & & 0 & & & 0 & & & 0 & & & 0 & 2 & 1 & 7 \\
\hline & 22 & $\square$ & & & & 0 & & & & 0 & & 0 & & $\square$ & & & & & 0 & & & 0 & & & 0 & & & 0 & & & 0 & 2 & 2 & 6 \\
\hline \multicolumn{2}{|c|}{ Soma 1} & 18 & 1 & 3 & 10 & 8 & 4 & 8 & 5 & 9 & 7 & 11 & 4 & 4 & 10 & 7 & 0 & 3 & 19 & 1 & 5 & 16 & $\mathbf{0}$ & 7 & 15 & 0 & 8 & 14 & 2 & 6 & 14 & & & \\
\hline \multicolumn{2}{|c|}{ Média 1} & & & & & & & & & & & & & & & & & & & & & & & & & & & & & & & 2,32 & 2,86 & 4,82 \\
\hline
\end{tabular}

${ }^{*} \mathrm{R}(\square)$ - Processo Racional; ${ }^{* *} \mathrm{P}(\diamond)$ - Processo Pseudorracional; e ${ }^{* * *} \mathrm{C}(\circ)$ - Processo Comportamental Fonte: Dados da pesquisa.

Revista Contemporânea de Contabilidade, Florianópolis, v. 17, n. 43, p. 51-70, abr./jun., 2020.

Universidade Federal de Santa Catarina. ISSN 2175-8069. DOI: https://doi.org/10.5007/2175-8069.2020v17n43p51 
Figura 4: Mapa-resumo de decisão do analista

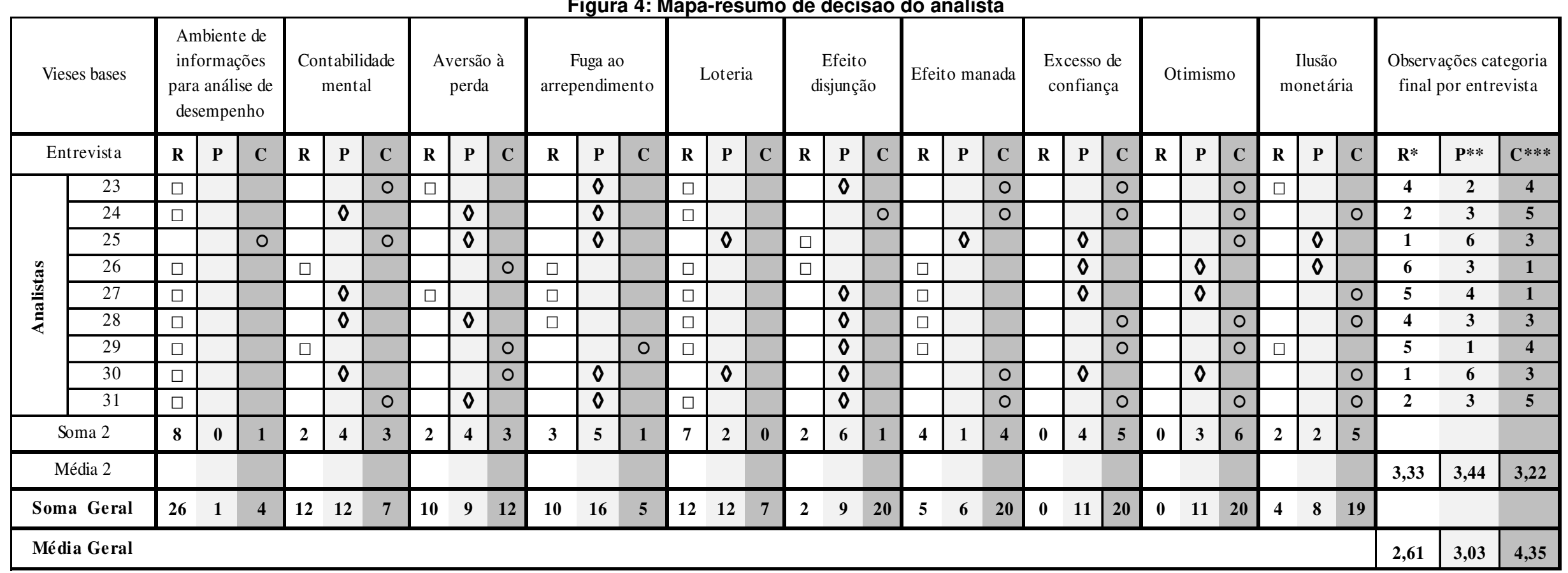

${ }^{\star} \mathrm{R}(\square)$ - Processo Racional; ${ }^{* \star} \mathrm{P}(\diamond)$ - Processo Pseudorracional; e ${ }^{\star \star *} \mathrm{C}(\circ)$ - Processo Comportamental Fonte: Dados da pesquisa.

Figura 5: Teste de média de investidores versus analistas

\begin{tabular}{|l|l|}
\hline \multicolumn{2}{|c|}{ Teste de Média não paramétrico Mann-Whitney U Test. } \\
\hline Processo Racional & O Z-Score é -1.37086. O p-value é .17068. O resultado não é significativo emp $<.05$ \\
\hline Processo Pseudorracional & O Z-Score é -1.08799. O p-valor é .27572. O resultado não é significativo emp $<.05$. \\
\hline Processo Comportamental & O Z-Score é 2.19773. O p-valor é .0278. O resultado é significativo emp $<0,05$ \\
\hline
\end{tabular}

Fonte: Dados da pesquisa. 
Para $65 \%$ dos entrevistados, seu processo de formação na tomada de decisão é essencialmente comportamental, quando sujeitos aos vieses Efeito Disjunção, Efeito Manada e Excesso de Confiança. A menor incidência desse processo na tomada de decisão constatou-se nos vieses Fuga ao Arrependimento (16\%), Contabilidade Mental (23\%) e Loteria (23\%). Destaca-se também que, em relação ao Ambiente de informações para análise de desempenho da empresa, do negócio e do mercado, $13 \%$ dos entrevistados são influenciados pelo processo comportamental. $\mathrm{Na}$ Tabela 1, apresenta-se a média geral de cada processo, bem como a média por tipo de entrevista (investidor e analista).

Tabela 1: Média de incidência de cada processo decisório

\begin{tabular}{lccc}
\hline Processos/Amostra & Total (31) & Investidores (22) & Analistas (09) \\
\hline Processo Racional & 2,61 & 2,32 & 3,33 \\
\hline Processo Pseudorracional & 3,03 & 2,86 & 3,44 \\
\hline Processo Comportamental & 4,35 & 4,82 & 3,22 \\
\hline Peso Total dos Quesitos & 10,00 & 10,00 & 10,00 \\
\hline
\end{tabular}

Fonte: Dados da pesquisa.

Observa-se, na Tabela 1, quanto à média geral, que investidores e analistas têm, respectivamente, no processo comportamental, a maior $(4,35 / 10)$ incidência na formação da tomada de decisão e, no processo racional, a menor $(2,61 / 10)$. Considerando que o processo pseudorracional $(3,03 / 10)$ também carrega uma parcela comportamental, pôde-se inferir que 7,38/10 do processo de formação da tomada de decisão é comportamental. Isso, porém, não permite afirmar que o processo decisório seja mais comportamental que racional, pois há mais fatores teoricamente comportamentais. Logo, já era esperado que o processo comportamental obtivesse um valor maior.

Ao separar investidores de analistas, observou-se que os investidores são os que sofrem maior incidência do processo comportamental na formação da tomada de decisão $(4,82 / 10)$, tendo, essencialmente, aspectos comportamentais na sua formação da tomada de decisão, contra 3,22/10 dos analistas. Percebeuse ainda que os investidores são os que sofrem menor influência do processo racional $(2,32 / 10)$ na formação de seu processo decisório. Para os analistas, há um equilíbrio entre os três processos na formação da tomada de decisão com ligeira vantagem para o processo pseudorracional $(3,44 / 10)$ frente ao processo racional $(3,33 / 10)$ e ao processo comportamental $(3,22 / 10)$.

Para validar as diferenças de médias entre investidores e analistas do mercado financeiro, realizouse o teste de médias não paramétrico Mann-Whitney $U$ Test para cada um dos três processos decisórios (Figura 5). Considerando um nível de significância de 5\% para os processos racional e pseudorracional, esses processos de tomada de decisão são, na média, semelhantes entre os investidores e os analistas do mercado financeiro. Para o processo comportamental, com um nível de significância de 2,78\% na média, aceita-se que haja diferença no processo de tomada de decisão entre investidores e analistas.

Individualmente, destaca-se o analista da entrevista 26 , com $60 \%$ de seu processo decisório sendo racional, e o da entrevista 27, com 50\% (Figura 4). Já para os investidores, a maior racionalidade no processo decisório foi a demonstrada pelas entrevistas 14 e 16, com $40 \%$ do seu processo decisório sendo racional (Figura 3). No quesito racionalidade, tem-se, nos analistas das entrevistas 25 e 30, a menor incidência, com apenas $10 \%$ de seus processos decisórios sendo racionais; nos investidores, a menor incidência (10\%) foi observada nas entrevistas 5, 7, 8, 9, 10 e 11 (Figura 4).

No processo pseudorracional, identificou-se, nos analistas das entrevistas 25 e 30 e nos investidores das entrevistas 4 e 8 , a maior incidência, com $60 \%$ de seus processos decisórios sendo considerados pseudorracionais (Figura 4). Observou-se que os analistas que mais sofrem influência desse processo são os mesmos que sofreram menos influência do processo racional (Figura 4). Destacam-se ainda os investidores das entrevistas 5, 12 e 19, com 50\% de suas decisões sendo consideradas pseudorracionais (Figura 3). Os investidores que menos estão sujeitos a esse processo pseudorracional, com apenas $10 \%$, são os das entrevistas 11, 14, 16 e 21 (Figura 3). Para os analistas das entrevistas 23, 24 e 29, o menor percentual foi de $20 \%$ do processo de decisão sendo considerado pseudorracional (Figura 4).

Em relação ao processo comportamental na formação da tomada de decisão, destaca-se o investidor da entrevista 8 , com $80 \%$ de seu processo decisório sendo orientado por aspectos comportamentais, os investidores das entrevistas 7, 10 e 21 , com $70 \%$, e os investidores das entrevistas 9, 15, 20 e 22), com $60 \%$ de suas decisões sendo orientadas por aspectos comportamentais (Figura 3). Para os analistas das entrevistas 24 e 31, há uma maior incidência desse processo com $50 \%$, e a menor incidência ocorre com os analistas das entrevistas 25 e 26, com apenas 10\% (Figura 4).

Diante dos resultados apresentados na Análise de Conteúdo das entrevistas de investidores e analistas do mercado financeiro mediante a construção dos processos na formação da tomada de decisão, conclui-se que "A construção do processo decisório do investidor e do analista do mercado em relação às empresas com Patrimônio Líquido Negativo é influenciada pelos vieses comportamentais", pois, como observado na análise, estes sofrem influências dos vieses comportamentais na formação do processo da tomada de decisão.

Também se conclui que "Esta influência dos vieses comportamentais ocorre em grau diferente de intensidade em relação ao investidor e ao analista do mercado", conforme observado neste estudo. Os 
investidores sofrem mais influência dos vieses comportamentais na formação do processo da tomada de decisão. Diferenças de influências dos vieses comportamentais na tomada de decisão também foram encontradas no estudo de Cazzari (2017), que comparou o processo decisório de estudantes da graduação do curso de Economia, Administração e Contabilidade da Universidade de São Paulo (USP) a 55 analistas de uma grande empresa, confrontados com a publicação das demonstrações econômicas financeiras das empresas.

\section{Considerações Finais}

A formação do processo decisório de investidores e analistas do mercado financeiro tem suscitado discussões entre pesquisadores e profissionais da área de investimentos. Nessa direção, este estudo teve como proposta identificar as motivações dos investidores $e$ analistas do mercado financeiro de aplicarem/recomendarem investimentos em empresas com PLN. A linha seguida neste estudo considerou que, na formação do processo da tomada de decisão, investidores e analistas do mercado financeiro fundamentam suas decisões em questões racionais, embasados na Teoria Moderna de Finanças, cujo objetivo é maximizar o resultado desse investimento. Porém, algumas dessas decisões de investidores e analistas podem não estar certas, e esses erros podem não ser aleatórios. Assim, é possível explicar uma parcela desse processo na formação da tomada de decisão por questões emocionais fundamentadas nas Finanças Comportamentais.

Os resultados encontrados por meio da Análise de Conteúdo, tendo como base as premissas da HME e das FC, conduziram a três categorias de processo na formação da tomada de decisão: "Processo racional na formação da tomada de decisão"; "Processo pseudorracional na formação da tomada de decisão"; e "Processo comportamental na formação da tomada de decisão, respectivamente, primeira, segunda e terceira categorias. A primeira atende à premissa da $\mathrm{HME}$ de que tanto o investidor quanto os analistas são racionais; a segunda atende parcialmente à premissa da HME, quanto atende parcialmente à premissa das FC; e a terceira atende à premissa das FC.

Os resultados demonstram que nenhum dos investidores ou dos analistas do mercado financeiro pode ser individualmente classificado dentro de uma categoria específica. Nesse sentido, não há um processo totalmente racional, pseudorracional ou comportamental.

Diante do exposto, esta pesquisa apresentou contribuições para estudos na área de finanças, notadamente ao integrar, neste estudo, a Teoria Moderna de Finanças e a Teoria de Finanças Comportamentais. Nesse sentido, contribuiu para o avanço na literatura.

De forma pretensiosa, esta pesquisa trouxe para discussão, no meio acadêmico, uma categoria até então não encontrada nos estudos de Finanças Comportamentais: o Processo pseudorracional na formação da tomada de decisão. Importante lembrar que, embora esta pesquisa insira essa categoria, assume-se que ela seja parte integrante das Finanças Comportamentais.

Outro aspecto a ser considerado, foi que o estudo ao abordar as finanças comportamentais, utilizou na amostra atores reais do mercado financeiro, diferente, por exemplo, do trabalho de Goulart (2014), que utilizou experimento com estudantes, e dos trabalhos de Steppan (2016), Braga (2015), além de Goulart (2014) que em seus estudos abordaram um único viés comportamental, este estudo contemplou uma gama maior de vieses comportamentais, para fundamentar o processo de formação da tomada de decisão de investidores e analistas.

Houve limitações na composição da amostra da pesquisa, pois, fora do meio acadêmico, o pesquisador, em alguns casos, é visto com desconfiança. Prova disto foi o baixo número de analistas e investidores que aceitaram participar, frente ao número de contatos realizados. Uma possível explicação para o baixo número de participantes pode ser o Efeito Vergonha, em que o investidor e/ou o analista procura não dar publicidade de suas perdas, tema objeto dos estudos de Goulart (2014). Para a busca, o acesso aos investidores e aos analistas e o aceite desses profissionais para participar da pesquisa, fez-se necessária a utilização de diversas estratégias, tais como envio de e-mails às empresas, ao responsável pela relação com investidores, visitas a empresas e a corretoras e ainda utilização de uma rede de cooperação, como fóruns de investidores.

Diante dessas limitações, este estudo não pode ser generalizado. Para suavizar tais limitações, recomenda-se estudo semelhante com investidores e analistas que operam somente com empresas com Patrimônio Líquido Positivo, a fim de verificar se os resultados correspondem aos encontrados neste estudo. Ainda se sugere pesquisar a influência das Finanças Comportamentais no processo de tomada de decisão de investidores day trade nos diversos meios de atuação do mercado, tais como ações, câmbio, mercado futuro, etc.

\section{Referências}

AINIA, Nadya Septi Nur; LUTFI, Lutfi. The influence of risk perception, risk tolerance, overconfidence, and loss aversion towards investment decision making. Journal of Economics, Business, \& Accountancy Ventura, v. 21, n. 3, p. 401-413, 2019. https://doi.org/10.14414/jebav.v21i3.1663 
ANG, Tze Chuan Chewie. Are Firms with Negative Book Equity in Financial Distress?. Review of Pacific Basin Financial Markets and Policies, v. 18, n. 03, p. 1550016, 2015.

https://doi.org/10.1142/S0219091515500162

B3 - Brasil, Bolsa e Balcão. Índice Bovespa. Empresas listadas. Disponível em:

www.bmfbovespa.com.br/pt_br/produtos/listados-a-vista/empresas-listadas.htm. Acesso em 04/08/2018.

BALI, Turan G.; CAKICI, Nusret; WHITELAW, Robert F. Maxing out: Stocks as lotteries and the crosssection of expected returns. Journal of Financial Economics, v. 99, n. 2, p. 427-446, 2011.

https://doi.org/10.1016/j.jfineco.2010.08.014

BARBERIS, Nicholas; THALER, Richard. A survey of behavioral finance. Handbook of the Economics of Finance, v. 1, p. 1053-1128, 2003. https://doi.org/10.1016/S1574-0102(03)01027-6

BARDIN, Laurence. Análise de conteúdo (Edição revista e atualizada). Lisboa: Edições, v. 70, 2009.

BENARTZI, Shlomo; KAHNEMAN, Daniel; THALER, Richard. Optimism and overconfidence in asset allocation decisions, Morningstar.com, 1999. Disponível em:

http://behaviouralfinance.net/optimism/Morningstar_com\%200ptimism\%20and\%20Overconfidence\%20in\%2 0Asset\%20Allocation\%20Decisions.htm

BODIE, Z. KANE, A. MARCUS, A. J. Investimentos. Porto Alegre: Bookman, 2015.

BRAGA, Robson. Ganhos e perdas em investimentos: um estudo experimental sobre personalidades à luz da teoria do prospecto e do efeito disposição. Tese de Doutorado. Universidade de São Paulo. São Paulo, 2015. https://doi.org 10/11606/T.12.2016.tde-04022016-132731

BROWN, Stephen; LAJBCYGIER, Paul; LI, Bob. Going Negative: What to Do with Negative Book Equity Stocks (Digest Summary). Journal of Portfolio management, v. 35, n. 1, p. 95-102, 2008.

https://doi.org/10.3905/JPM.2008.35.1.95

CARDOSO, Ricardo Lopes et al. A ilusão monetária e a informação contábil e financeira. Revista Universo Contábil, v. 6, n. 2, p. 47-60, 2010. https://doi.org/10.4270/ruc.2010212

CAZZARI, R. B. Tomada de decisão, heurísticas e vieses na análise das demonstrações contábeis. USP. Tese. Universidade de São Paulo, São Paulo, 2017. https://doi.org/10.11606/T.12.2017.tde-24022017101355

CHENITZ, W. Carole; SWANSON, Janice M. From practice to grounded theory: Qualitative research in nursing. Prentice Hall, 1986.

CIPRIANI, Marco GUARINO, Antonio. Herd behavior and contagion in financial markets. The BE Journal of Theoretical Economics, v. 8, n. 1, p. 1-54, 2008. https://doi.org/10.2202/1935-1704.1390

COELHO, Luis et al. Bankruptcy Sells Stocks... But Who's Buying (and Why)? In: SSRN, 2427770, 2014. https://dx.doi.org/10.2139/ssrn.2427770

COLLINS, Daniel W.; PINCUS, Morton; XIE, Hong. Equity valuation and negative earnings: The role of book value of equity. The Accounting Review, v. 74, n. 1, p. 29-61, 1999.

https://doi.org/10.2308/accr.1999.74.1.29

CORTER, James E.; CHEN, Yuh-Jia. Do investment risk tolerance attitudes predict portfolio risk? Journal of Business and Psychology, v. 20, n. 3, p. 369, 2006. https://doi.org/10.1007/s10869-005-9010-5

DAMODARAM, A. Avaliação de investimentos: ferramentas e técnicas para a determinação do valor de qualquer ativo. Rio de Janeiro: Qualitymark, 2006.

ENGSTED, Tom; PEDERSEN, Thomas Quistgaard. The predictive power of dividend yields for future inflation: Money illusion or rational causes? In: SSRN, 2016. Disponível em:

https://papers.ssrn.com/sol3/papers.cfm?abstract_id=2768320. Acesso em 04/04/2017.

FAMA, Eugene F. Efficient capital markets: a review of theory and empirical work. Journal of Finance, v. 
25, n. 2, p. 383-417, 1970. https://doi.org/10.1111/j.1540-6261.1970.tb00518.x

FAMA, Eugene F. Efficient capital markets: II. The Journal of Finance, v. 46, n. 5, p. 1575-1617, 1991. https://doi.org/10.1111/j.1540-6261.1991.tb04636.x

FAMA, Eugene F.; FRENCH, Kenneth R. The cross-section of expected stock returns. The Journal of Finance, v. 47, n. 2, p. 427-465, 1992. https://doi.org/10.1111/j.1540-6261.1992.tb04398.x

FAMA, Eugene F.; FRENCH, Kenneth R. A five-factor asset pricing model. Journal of Financial Economics, v. 116, n. 1, p. 1-22, 2015. https://doi.org/10.1016/j.ffineco.2014.10.010

FEHR, Ernst; TYRAN, Jean-Robert. Does money illusion matter? American Economic Review, p. 12391262, 2001. DOI: 10.1257/aer.91.5.1239

FERREIRA, Janayna K. F. de Souza; SILVA, Rhoger F. Marinho da; GUILHERME, Hipónio Fortes. Um panorama evolutivo das finanças e a aplicação das finanças comportamentais na análise de tomada de decisão dos investidores no mercado de capitais. In: III Seminário UFPE de Ciências Contábeis, 2009. Anais..., 2009.

GLASER, B.; STRAUSS, A. The discovery of grounded theory: Strategies for qualitative research. New York: Aldine Publishing Company, 1967.

GOULART, Marco Antonio de Oliveira Vieira. Aversão à vergonha: um estudo em finanças comportamentais. Tese UFSC., 2014. https://repositorio.ufsc.br/xmlui/handle/123456789/129174

HAN, Bing; KUMAR, Alok. Speculative retail trading and asset prices. Journal of Financial and Quantitative Analysis, v. 48, n. 02, p. 377-404, 2013. https://doi.org/10.1017/S0022109013000100

HAUGEN, Robert A. Os segredos da bolsa: como prever resultados e lucrar com ações. São Paulo: Pearson Brasil, 2005.

HAYN, Carla. The information content of losses. Journal of Accounting and Economics, v. 20, n. 2, p. 125-153, 1995.

HOU, Kewei; ZHANG, Yinglei; ZHUANG, Zili. Understanding the Variation in the Information Content of Earnings: A Return Decomposition Analysis. Fisher College of Business Working Paper, n. 2015-03-01, In: SSRN, 2015. https://dx.doi.org/10.2139/ssrn.2548688

HSU, Kathy HY; ETHERIDGE, Harlan L. Negative Earnings In International Equity Valuation. International Business \& Economics Research Journal (IBER), v. 8, n. 3, 2009. https://doi.org/10.19030/iber.v8i3.3111

IUDÍCIBUS, S. Análise de balanços: análise da liquidez e do endividamento, análise do giro, rentabilidade e alavancagem financeira, indicadores e análises especiais (análise de tesouraria de Fleuriet, EVA, DVA e EBITDA). 10ª ed. São Paulo: Atlas, 2009.

JAN, Ching-Lih; OU, Jane A Negative-book-value firms and their valuation. Accounting Horizons, v. 26, n. 1, p. 91-110, 2012. https://doi.org/10.2308/acch-50094

JENKINS, David S. The transitory nature of negative earnings and the implications for earnings prediction and stock valuation. Review of Quantitative Finance and Accounting, v. 21, n. 4, p. 379-404, 2003. https://doi.org/10.1023/B:REQU.0000004784.30694.0c

KAHNEMAN, Daniel. Rápido e devagar: duas formas de pensar. Rio de Janeiro: Objetiva, 2012.

KURDOGLU, Rasim Serdar. An inquiry into pseudo-legitimations: A framework to investigate the clash of managerial legitimations and employees' unfairness claims. Business Ethics: A European Review, v. 28, n. 1, p. 129-138, 2019. https://doi.org/10.1111/beer.12202

LAKONISHOK, Josef; SHLEIFER, Andrei; VISHNY, Robert W. The impact of institutional trading on stock prices. Journal of Financial Economics, v. 32, n. 1, p. 23-43, 1992. https://doi.org/10.1016/0304405X(92)90023-Q 
LEONTIEF, Wassily W. The Fundamental Assumption of Mr. Keynes' Monetary Theory of Unemployment. The Quarterly Journal of Economics, v. 51, n. 1, p. 192-197, 1936. DOI: 10.2307/1882507

LICHTENSTEIN, Sarah; FISCHHOFF, Baruch. Do those who know more also know more about how much they know?. Organizational Behavior and Human Performance, v. 20, n. 2, p. 159-183, 1977. https://doi.org/10.1016/0030-5073(77)90001-0

MACEDO, Marcelo A. Silva; FONTES, Patrícia Vivas da Silva. Análise do comportamento decisório de analistas contábil-financeiros: um estudo com base na Teoria da Racionalidade Limitada. Revista Contemporânea de Contabilidade, v. 6, n. 11, p. 159-186, 2010. https://doi.org/10.5007/21758069.2009v6n11p159

MARKOWITZ, Harry. Portfolio selection. The Journal of Finance, v. 7, n. 1, p. 77-91, 1952.

MODIGLIANI, Franco.; MILLER, Merton. H. Dividend policy, growth, and the valuation of shares. The Journal of Business, v. 34, n. 4, p. 411-433, 1961. https://www.jstor.org/stable/2351143

MODIGLIANI, Franco.; MILLER, Merton. H. The cost of capital, corporation finance, and the theory of investiment. American Economic Review, Nashville, v. 48, n. 3, p. 261-297, June 1958.

https://www.jstor.org/stable/1809766

NAWROCKI, David; VIOLE, Fred. Behavioral finance in financial market theory, utility theory, portfolio theory and the necessary statistics: a review. Journal of Behavioral and Experimental Finance, v. 2, p. 10-17, 2014. https://doi.org/10.1016/j.jbef.2014.02.005

ODEAN, Terrance. Are investors reluctant to realize their losses? The Journal of Finance, v. 53, n. 5, p. 1775-1798, 1998. https://doi.org/10.1111/0022-1082.00072

OSBORNE, MF Maury. Brownian motion in the stock market. Operations Research, v. 7, n. 2, p. 145-173, 1959. https://doi.org/10.1287/opre.7.2.145

ROBERTS, Harry V. Stock-Market "Patterns" And Financial Analysis: Methodological Suggestions. The Journal of Finance, v. 14, n. 1, p. 1-10, 1959. http://dx.doi.org/10.2307/2976094

ROGERS, Pablo; SECURATO, José R.; RIBEIRO, Karem. Finanças comportamentais no Brasil: um estudo comparativo. Revista de Economia e Administração, São Paulo, v. 6, n.1, p. 49-68, 2007. DOI:

10.11132/rea.2002.144

ROSS, Stephen A. Uncertainty and the heterogeneous capital good model. The Review of Economic Studies, v. 42, n. 1, p. 133-146, 1975. DOI: 10.2307/2296827

SCHARFSTEIN, David S.; STEIN, Jeremy C. Herd behavior and investment. The American Economic Review, p. 465-479, 1990. https://www.jstor.org/stable/2006678

SHAFIR, Eldar; DIAMOND, Peter; TVERSKY, Amos. Money illusion. The Quarterly Journal of Economics, v. 112, n. 2, p. 341-374, 1997. https://doi.org/10.1162/003355397555208

SHARPE, William F. Mutual fund performance. The Journal of Business, v. 39, n. 1, p. 119-138, 1966. https://www.jstor.org/stable/2351741

SHARPE, William F. Capital asset prices: A theory of market equilibrium under conditions of risk. The Journal of Finance, v. 19, n. 3, p. 425-442, 1964. https://doi.org/10.1111/j.1540-6261.1964.tb02865.x

SHEFRIN, Hersh; STATMAN, Meir. The disposition to sell winners too early and ride losers too long: Theory and evidence. The Journal of Finance, v. 40, n. 3, p. 777-790, 1985. https://doi.org/10.1111/j.15406261.1985.tb05002.x

SILVA, Valéria L. A. M. Proposta de uma sistemática dinâmica de otimização de portfólio: um desenvolvimento a partir das finanças comportamentais. UFPE. Tese Programa de Pós-Graduação em Administração da Universidade Federal de Pernambuco, Recife, 2016.

https://repositorio.ufpe.br/handle/123456789/18617

SIMON, Hebert. A. Theories of decision-making in economics and behavioral science. American Economic 
Review, 49, 253-283, 1957. https://www.jstor.org/stable/1809901

SOUZA, Antonio Artur de et al. Avaliação da satisfação dos usuários de sistemas de informações financeiras. In: VI CONGRESSO USP DE CONTROLADORIA E CONTABILIDADE, 2006. Anais..., 2006.

STEPPAN, Adriana Isabel Backes. Uma análise da influência do viés de otimismo no julgamento de probabilidades de ativos e passivos contingentes. 2016. Tese (Doutorado)-Programa Multilnstitucional e Inter-Regional de Pós-Graduação em Ciências Contábeis da UnB, UFPB, UFRN.

http://dx.doi.org/10.26512/2016.04.T.20909

THALER, Richard H. Mental accounting matters, Journal of Behavioral Decision Making. v. 12, p. 183206.1999. https://doi.org/10.1002/(SICI)1099-0771(199909)12:3<183::AID-BDM318>3.0.CO;2-F

TVERSKY, Amos; KAHNEMAN, Daniel. Judgment under uncertainty: Heuristics and biases. Science, v. 185, n. 4157 , p. 1124-1131, 1974. DOI: 10.1126/science.185.4157.1124

TVERSKY, Amos; KAHNEMAN, Daniel. Prospect theory: An analysis of decision under risk. Econometrica, v. 47, n. 2, p. 263-291, 1979.

TVERSKY, Amos; KAHNEMAN, Daniel. The framing of decisions and the psychology of choice. Science, $v$. 211, n. 4481, p. 453-458, 1981. DOI: 10.1126/science.7455683

TVERSKY, Amos; SHAFIR, Eldar. The disjunction effect in choice under uncertainty. Psychological Science, v. 3, n. 5, p. 305-309, 1992. https://doi.org/10.1111/j.1467-9280.1992.tb00678.x

YOSHINAGA, Claudia Emiko et al. Finanças comportamentais: Uma introdução. REGE. Revista de Gestão, v. 15 , n. 3, p. 25 , 2008. https://doi.org/10.5700/issn.2177-8736.rege.2008.36644

\section{NOTAS}

\section{AGRADECIMENTOS}

Não se aplica

\section{CONTRIBUIÇÃO DE AUTORIA}

Concepção e elaboração do manuscrito: J. A. Cescon

Coleta de dados: J. A. Cescon

Análise de dados: J. A. Cescon; R. F. Decourt; L. A. Costa

Discussão dos resultados: J. A. Cescon; R. F. Decourt; L. A. Costa

Revisão e aprovação: R. F. Decourt; L. A. Costa

\section{CONJUNTO DE DADOS DE PESQUISA}

O conjunto de dados que dá suporte aos resultados deste estudo não está disponível publicamente.

\section{FINANCIAMENTO}

Não se aplica

\section{CONSENTIMENTO DE USO DE IMAGEM}

Não se aplica.

\section{APROVAÇÃO DE COMITÊ DE ÉTICA EM PESQUISA \\ Não se aplica.}

\section{CONFLITO DE INTERESSES}

Não se aplica.

\section{LICENÇA DE USO}

Os Direitos Autorais para artigos publicados neste periódico são do autor, com direitos de primeira publicação para a Revista. Em virtude de aparecerem nesta Revista de acesso público, os artigos são de uso gratuito, com atribuições próprias, em aplicações educacionais, de exercício profissional e para gestão pública. A Revista adotou a licença Creative Commons Atribuição 4.0 Internacional - CC BY NC ND. Esta licença permite acessar, baixar (download), copiar, imprimir, compartilhar, reutilizar e distribuir os artigos desde que com a citação da fonte, atribuindo os devidos créditos de autoria. Nesses casos, nenhuma permissão é necessária por parte dos autores ou dos editores. Autores têm autorização para assumir contratos adicionais separadamente, para distribuição não-exclusiva da versão do trabalho publicada nesta revista (ex.: publicar 
em repositório institucional ou um capítulo de livro).

\section{PUBLISHER}

Universidade Federal de Santa Catarina. Curso de Ciências Contábeis e Programa de Pós-graduação em Contabilidade. Publicação no Portal de Periódicos UFSC. As ideias expressadas neste artigo são de responsabilidade de seus autores, não representando, necessariamente, a opinião dos editores ou da universidade.

\section{EDITORES}

Carlos Eduardo Facin Lavarda e Suliani Rover

\section{HISTÓRICO}

Recebido em: 12/07/2018 - Revisado por pares em: 20/04/2020 - Reformulado em: 18/05/2020 Recomendado para publicação em: 05/06/2020 - Publicado em: 30/06/2020 